\title{
Solid-state Fermentation of Acanthogobius hasta Processing By-products for the Production of Antioxidant Protein Hydrolysates with Aspergillus oryzae
}

\author{
Yaowei Fang ${ }^{1,2,3^{*}}$, Shujun Wang ${ }^{1,2,3}$, Shu Liu ${ }^{1}$, Mingsheng $\mathrm{Lu}^{1}$, Yuliang Jiao ${ }^{1}$, Guoqiang \\ Chen $^{1}$ and Jianmei Pan ${ }^{1}$ \\ ${ }^{1}$ School of Marine Science and Technology; Huaihai Institute of Technology; Lianyungang - China. ${ }^{2}$ Jiangsu Key \\ Laboratory of Marine Pharmaceutical Compound Screening; Huaihai Institute of Technology; Lianyungang - \\ China. ${ }^{3}$ Co-Innovation Center of Jiangsu Marine Bio-industry Technology; Huaihai Institute of Technology; \\ Lianyungang - China
}

\begin{abstract}
Functional properties and antioxidative activity of a protein hydrolysate prepared from Acanthogobius hasta processing by-product protein during solid-state fermentation with Aspergillus oryzae were investigated. Overall, protease activity increased with the degree of hydrolysis $(\mathrm{DH})$ decreased during solid-state fermentation. All the protein hydrolysate had excellent solubility, possessed interfacial properties, and varying degrees of antioxidant activity which were governed by their concentrations and DH, molecular weight distribution and amino acid composition. After 5 days fermentation, the DH of the protein hydrolysate was $31.23 \%$. The protein hydrolysate had the highest total hydrophobic amino acid content, the highest DPPH scavenging activity, reducing power, and the chelating activity. The radical-scavenging activity of the hydrolysates at $6 \mathrm{mg} / \mathrm{mL}$ was $78.6 \%$. The reducing power of protein hydrolysate at the range of $0-6 \mathrm{mg} / \mathrm{mL}$ was lower than that of BHA at the range of $0-60 \mu \mathrm{g} / \mathrm{mL}$, while the chelating activity of APs was similar to that of BHA at the range of $0-60 \mu \mathrm{g} / \mathrm{mL}$. Moreover, the protein hydrolysate showed good emulsifying and foaming properties over a wide $\mathrm{pH}$ range from 2 to 12 . Therefore, solid state fermentation provided a suitable and low-cost method for converting Acanthogobius hasta processing by-product protein into antioxidant protein hydrolysates.
\end{abstract}

Key words: functionalities and antioxidant properties, Acanthogobius hasta processing by-product, Solid state fermentation, protein hydrolysates, Aspergillus oryzae

\section{INTRODUCTION}

Annually, over 100 million tons of fish are harvested worldwide, and approximately $30 \%$ of the total catch is used for fishmeal and animal feed because of its poor functional properties ( $\mathrm{Je}$ et al. 2007). Moreover, the byproduct of fish processing was looked as worthless garbage and discarded without an attempt of recovery, and which resulted in different level of environmental pollution (Castro-Cesena et al. 2012). Actually, these underutilized fish and by-products have been reported to be good source of proteins (Chalamaiah et al. 2012). If these proteins can be utilized efficiently, it would serve the dual purpose of raising economy benefit and reducing the pollution problems that could arise (Bhaskar et al. 2008). Recently, several studies have been reported that these underutilized fish and byproducts can be converted to value-added products

*Author for correspondence: fangyw@ hhit.edu.cn 
by enzymatic hydrolysis, which is widely applied to improve and upgrade the functional and nutritional properties of food proteins (Khantaphant et al. 2008).

Uncontrolled lipid peroxidation is a major cause of numerous chronic and age specific diseases (Cho et al. 2013). The etiology of these diseases is associated with the generation of excess free radicals such as superoxide anion and hydroxyl radical. Free radicals react rapidly with other chemical groups or substances in the body, which leading to proteins, DNA, cell or tissue injury (Je et al. 2009). An antioxidant can eliminate free radicals and thus eliminating the cause of these diseases (Halliwell et al. 1986). Therefore, during last few decades there is a continuing search for better and more effective antioxidants. Synthetic antioxidants have been widely used in food products to delay the deterioration caused by lipid oxidation. However, these antioxidants pose potential health hazards, and their use is restricted in some countries. Hence, it is essential to develop safe and natural antioxidants as alternatives to synthetic ones (Ktari et al. 2012; Kim et al. 2013). Fish protein hydrolysate has been found to be one of best antioxidants. Numerous fish protein hydrolysates such as skin gelatin hydrolysates from brownstripe red snapper, cuttlefish (Sepia officinalis) and grey triggerfish (Balistes capriscus) or meat protein hydrolysates from yellow trevally, mackerel, loach, smooth hound (Mustelus mustelus), bigeye tuna (Thunnus obesus), grass carp (Ctenopharyngodon idellus) and sardinelle (Sardinella aurita) have been reported to exhibit antioxidative activity. And what's more, FPH can be used in food systems, comparable to other pertinent protein hydrolysates (Chalamaiah et al. 2012; Ktari et al. 2012).

Acanthogobius hasta, marine fish belonging to the suborder Gobiodei, is one of the main raw materials in in East Asia and also widely cultured in China's coastal regions. The yield of Acanthogobius hasta is going up continually. Martins et al. (2014) found solid state fermentation was an easy and low cost way to product protease using insoluble fish protein residue as substrate. Our previous studies showed the feasibility of preparing Acanthogobius hasta muscle protein hydrolysates both in liquid and solid state fermentation with Aspergillus oryzae. Moreover, the yield of protease and protein hydrolysate with better antioxidant activity was improved through optimizing the fermentation conditions (Fang et al. 2010; Fang et al. 2013). But the functionalities and antioxidant properties of the protein hydrolysates prepared from Acanthogobius hasta (APs) processing by-product were not clear yet. Hence, in the present study, the APs prepared in solid-state fermentation with Aspergillus oryzae were determined. Moreover, the molecular weight distribution and the amino acid composition level during fermentation were investigated to reveal their relations with antioxidant activities.

\section{MATERIAL AND METHODS}

\section{Reagents}

2, 2-diphenyl-1-picrylhydrazyl (DPPH), butylated hydroxyanisole (BHA), 3-(2-Pyridyl)-5, 6diphenyl-1, 2, 4-triasine-p, p'-disulphonic acid monosodium salt hydrate (ferrozine), and ethylenediaminetetraacetic acid (EDTA) were purchased from Sigma Chemical Co. (St. Louis, MO). Sephadex G-25 was produced by Pharmacia Biotech Co. (Uppsala, Sweden). Other chemicals and reagents used were analytical grade and commercially available. All solutions were freshly prepared in distilled water.

\section{Materials}

Frozen Acanthogobius hasta by-products were obtained from the fish-processing plant of Lianyungang, China. The frozen samples were thawed using the running water for $1 \mathrm{~h}$ as soon as the samples were transported to the laboratory. After being thawed, the samples were rinsed with cold distilled water, homogenised using a biohomogenizer at high speed for $1 \mathrm{~min}$, and then dried in an oven at $80^{\circ} \mathrm{C}$ for $18 \mathrm{~h}$. The dried byproducts preparation were minced to obtain a fine powder. The samples were packed in polyethylene bags and stored at $-20^{\circ} \mathrm{C}$ for not longer than 1 month.

\section{Solid-state fermentation}

Aspergillus oryzae AS3.951 (China General Microbiological Culture Collection Center, CGMCC) was taken from $-70^{\circ} \mathrm{C}$ frozen stock and transferred onto Potato dextrose agar (PDA) agar plates for $96 \mathrm{~h}$ at $30^{\circ} \mathrm{C}$ and stored at $4^{\circ} \mathrm{C}$ in a refrigerator for future use. The cultures were renewed every four weeks. The spore suspension was prepared by incubating the cultures on PDA plates at $30^{\circ} \mathrm{C}$ until sufficient sporulation was 
observed. The spores were harvested using $0.1 \%$ Tween 80 solution (v/v) and the spore count of about $1 \times 10^{7}$ cells $/ \mathrm{mL}$ was used for inoculation purposes (Dhillona et al. 2011).

Solid state fermentation (SSF) was carried out by taking $10 \mathrm{~g}$ of Acanthogobius hasta processing byproduct power in $250 \mathrm{~mL}$ Erlenmeyer flask. The moisture was adjusted to $50 \%(\mathrm{v} / \mathrm{v})$ with salt solution ( $\mathrm{pH} 7.5$ ) containing $0.1 \%$ dipotassium hydrogen phosphate, $0.5 \%$ magnesium sulphate, $0.5 \%$ sodium chloride and $0.004 \%$ ferrous sulphate. All the flasks were autoclaved at $121^{\circ} \mathrm{C}$ for $20 \mathrm{~min}$ and after cooling were inoculated with $1 \mathrm{~mL}$ of spore suspension and incubated at $30^{\circ} \mathrm{C}$ for the desired period (Sandhya et al. 2005). All the experiments were conducted in triplicates. Samples were withdrawn at $24 \mathrm{~h}$ intervals, and the protease and the protein hydrolysate were extracted. The activity of protease, the degree of hydrolysis and the DPPH radical scavenging activity of the hydrolysates were determined as described below.

\section{Protease extraction and assay}

The fermented matter was subjected to enzyme extraction by addition of $100 \mathrm{ml}$ phosphate buffer (0.1 M, pH 8.0). The flasks were shaken in an incubator shaker for about $30 \mathrm{~min}$ to obtain the enzyme extract in the solution form and the contents were then filtered through wet muslin cloth by thorough squeezing. The extract was centrifuged at $8,000 \mathrm{~g}$ at $4^{\circ} \mathrm{C}$ for $20 \mathrm{~min}$ and the supernatant was filtered with a cellulose acetate membrane filter (pore size, $0.22 \mu \mathrm{m}$ ) as crude protease for further analysis. The protease activity was assayed according to Kunitz (1947). All reaction was performed at $37^{\circ} \mathrm{C}$. One unit (U) of protease was equivalent to $1 \mu \mathrm{g}$ tyrosine liberated by the amount of enzyme per minute. The protease recovery was expressed as total units (U) of crude protease obtained per gram of dry substrate (gds).

\section{Protein hydrolysates extraction}

The fermented matter was transferred to Erlenmeyer flasks and the protein hydrolysates were extracted by adding distilled water to achieve a solid/liquid ratio of 1:10. The suspension was stirred at $160 \mathrm{rpm}$ for $30 \mathrm{~min}$ at room temperature, and then heated at $98^{\circ} \mathrm{C}$ for 10 $\mathrm{min}$ to inactivate the proteases. The whole contents were centrifuged at $10,000 \mathrm{~g}$ for $10 \mathrm{~min}$ at $4^{\circ} \mathrm{C}$. The supernatants were collected as APs and stored at $-20^{\circ} \mathrm{C}$ prior to the analyses.

\section{Protein concentration}

Protein concentration was determined by the method of Bradford (1976) using bovine serum albumin as a standard.

\section{Determination of a-amino acid content and degrees of hydrolysis}

The a-amino acid content and DH were determined according to the method of Nalinanon et al. (2011). To properly diluted hydrolysate samples $(125 \mu \mathrm{L}), 2.0 \mathrm{~mL}$ of $0.2 \mathrm{M}$ phosphate buffer $(\mathrm{pH} 8.2)$ and $1.0 \mathrm{~mL}$ of $0.01 \%$ TNBS solution were added. The solution was mixed thoroughly and placed in a temperature controlled water bath at $50^{\circ} \mathrm{C}$ for $30 \mathrm{~min}$ in the dark. The reaction was terminated by adding $2.0 \mathrm{~mL}$ of 0.1 $\mathrm{M}$ sodium sulphate. The mixtures were cooled at room temperature for $15 \mathrm{~min}$. The absorbance was read at $420 \mathrm{~nm}$ and $\alpha$-amino acid was expressed in terms of L-leucine.

DH was calculated as follows:

$\mathrm{DH}=\left[\left(\left(L_{t}-L_{0}\right)\right) /\left(\left(L_{\text {Max }}-L_{0}\right)\right)\right] \times 100$

Where $L t$ is the amount of a-amino acid released at time t. L0 is the amount of a-amino acid in the original acid-solubilised protein substrate. Lmax is total a-amino acid in the original acid-solubilised protein substrate obtained after acid hydrolysis (6 $\mathrm{M} \mathrm{HCl}$ at $100^{\circ} \mathrm{C}$ for $24 \mathrm{~h}$ ).

\section{Determination of DPPH radical scavenging activity, reducing power, and ferrous chelating activity}

The DPPH radical scavenging activity was determined according to the method of $\mathrm{He}$ et al. (2012). An aliquot of $2 \mathrm{~mL}$ of each samples at different concentrations were added to $2 \mathrm{~mL}$ of 0.1 $\mathrm{mM}$ DPPH dissolved in $95 \%$ ethanol. The mixture was shaken and left for $30 \mathrm{~min}$ at room temperature, and the absorbance of the resulting solution was measured at $517 \mathrm{~nm}$.

The reducing power and chelating activity of APs was determined according to the method of Ktari et al. (2012). An aliquot of $1 \mathrm{~mL}$ sample of each hydrolysate at different concentrations (1 to 6 $\mathrm{mg} / \mathrm{mL}$ ) was mixed with $2.5 \mathrm{~mL}$ of 0.2 Mphosphate buffer ( $\mathrm{pH}$ 6.6) and $2.5 \mathrm{~mL}$ of $1 \%$ $(\mathrm{w} / \mathrm{v})$ potassium ferricyanide solution. The mixtures were incubated for $30 \mathrm{~min}$ at $50^{\circ} \mathrm{C}$. After incubation, $2.5 \mathrm{~mL}$ of $10 \%(\mathrm{w} / \mathrm{v})$ TCA was added and the reaction mixtures were then centrifuged for $10 \mathrm{~min}$ at $10,000 \mathrm{~g}$. Finally, $2.5 \mathrm{~mL}$ of the 
supernatant solution from each sample mixture was mixed with $2.5 \mathrm{~mL}$ of distilled water and 0.5 $\mathrm{mL}$ of $0.1 \%(\mathrm{w} / \mathrm{v})$ ferric chloride. After a $10 \mathrm{~min}$ reaction time, the absorbance of the resulting solutions was measured at $700 \mathrm{~nm}$. Higher absorbance of the reaction mixture indicated higher reducing power. The control was conducted in the same manner, except that distilled water was used instead of the sample.

To $0.5 \mathrm{~mL}$ of sample solution at different concentrations ( 1 to $6 \mathrm{mg} / \mathrm{mL}$ ) was mixed with 1.6 $\mathrm{mL}$ of distilled water and $0.05 \mathrm{~mL}$ of $2 \mathrm{mM} \mathrm{FeCl}_{2}$, followed by the addition of $0.1 \mathrm{~mL}$ of ferrozine $(5$ $\mathrm{mM}$ ) after $15 \mathrm{~min}$. After a $20 \mathrm{~min}$ reaction time at room temperature, the absorbance was measured at $562 \mathrm{~nm}$. The blank was prepared in the same manner except that distilled water was used instead of the sample. EDTA was used as a standard. The control was conducted in the same manner, except that distilled water was used instead of sample. The test was carried out in triplicate.

\section{Molecular weight distribution}

After autoclave, before inoculation, the protein before fermentation (PBF) was extracted and used it as control hydrolysate to determine molecular weight distribution and functional properties. The molecular weight distribution of the hydrolysate was analyzed using Sephadex G25 column $(1.6 \times$ $50 \mathrm{~cm}$ ) (Nalinanon et al. 2011).

\section{Amino acid composition}

A LC-10Avp Plus HPLC (Shimadzu Co., Tokyo, Japan) coupled with an elite amino acid analysis column (Elite Analytical Instruments Co., Ltd., Dalian, Liaoning, China) were used to determine the amino acid composition of the APs (Zhou et al. 2012).

\section{Functional properties of protein hydrolysate}

The solubility, foam expansion, foam stability, emulsion activity index and the emulsion stability index of hydrolysates were determined by following the method of $\mathrm{Li}$ et al. (2012).

To determine protein solubility, $10 \mathrm{mg}$ hydrolysate samples dispersed in $10 \mathrm{~mL}$ of deionized water at room temperature and the $\mathrm{pH}$ of the mixture was adjusted to 2- 12 with either $1 \mathrm{M} \mathrm{HCl}$ or $1 \mathrm{M}$ $\mathrm{NaOH}$. The volume of solutions was made up to $10 \mathrm{~mL}$ by distiled water, previously adjusted to the same $\mathrm{pH}$ as the sample solution. The solution was centrifuged at $5000 \mathrm{~g}$ for $15 \mathrm{~min}$. Protein content in the supernatant was determined using the method of Bradford (1976). Total protein content in the sample was determined after solubilisation of the sample in $0.5 \mathrm{M} \mathrm{NaOH}$.

Twenty milliliters of hydrolysate solutions with different protein concentrations $(0.5 \%, 1 \%$ and $2 \% ; \mathrm{w} / \mathrm{v}$ ) in a $100 \mathrm{~mL}$ cylinder were homogenized for $1 \mathrm{~min}$ at room temperature. The whipped sample was then immediately transferred into a 50 $\mathrm{mL}$ graduated cylinder, and the total volume was measured immediately and at $30 \mathrm{~min}$ after whipping. Foam expansion and foam stability was expressed as percentage of volume increase after homogenization at 0 and $30 \mathrm{~min}$, respectively.

To determine the emulsion activity index and the emulsion stability index of the hydrolysates,

Ten milliliters of soybean oil and $30 \mathrm{~mL}$ of ZPHs solutions at different concentrations $(0.5 \%, 1 \%$ and $2 \% ; \mathrm{w} / \mathrm{v})$ were homogenized at room temperature. An aliquot of the emulsion $(50 \mu \mathrm{L})$ was pipetted from the middle portion of the container at 0 and $10 \mathrm{~min}$ after homogenization, and diluted 100 -fold with $0.1 \%$ sodium dodecyl sulphate SDS solution. The mixture was mixed thoroughly and the absorbance of the diluted solutions was measured at $500 \mathrm{~nm}$. The absorbances, measured immediately (A0) and 10 min (A10) after emulsion formation, were used to calculate the emulsifying activity index (EAI) and the emulsion stability index (ESI) as follows:

EAI $\left(\mathrm{m}^{2} \mathrm{~g}^{-1}\right)=\left(2 \times 2.303 \times A_{0}\right) /(0.25 \times$ protein weight $(\mathrm{g}))$

$\operatorname{ESI}(\min )=\mathrm{t} \times\left(A_{0}-A_{10}\right) /\left(A_{0}\right)$

\section{Statistical analysis}

All experiments and analyses were carried out in triplicate. The statistical analysis was performed by using SPSS 16.0 software (SPSS Inc. Chicago, IL, USA) using one-way analysis of variance (ANOVA). Comparisons that yielded $\mathrm{P}$ values $<0.05$ were considered significant.

\section{RESULTS AND DISCUSSION}

\section{Time course of protease activity and degree of hydrolysis during fermentation}

The time courses for hydrolysis of the Acanthogobius hasta processing by-product protein and the production of protease from Aspergillus oryzae were evaluated during a 6 days fermentation period. Samples were withdrawn at $24 \mathrm{~h}$ intervals, and the activity of protease, the 
degree of hydrolysis and the DPPH radical scavenging activity of the hydrolysates were determined. The results were illustrated in Figure 1. The crude protease activities on Acanthogobius hasta processing by-product in SSF increased rapidly after 3 days of fermentation. The maximum amount of protease about $10568 \mathrm{U} / \mathrm{gds}$ was observed at 4 days of fermentation. A maximal neutral protease activity at 3-4 days produced by Aspergillus oryzae NRRL 2160 cultivated on wheat bran in SSF has been also previously reported (Battaglino et al. 1991). However, other works revealed various fermentation times for Aspergillus oryzae according to the measured proteolytic activity and the substrate used (Belmessikh et al. 2013).

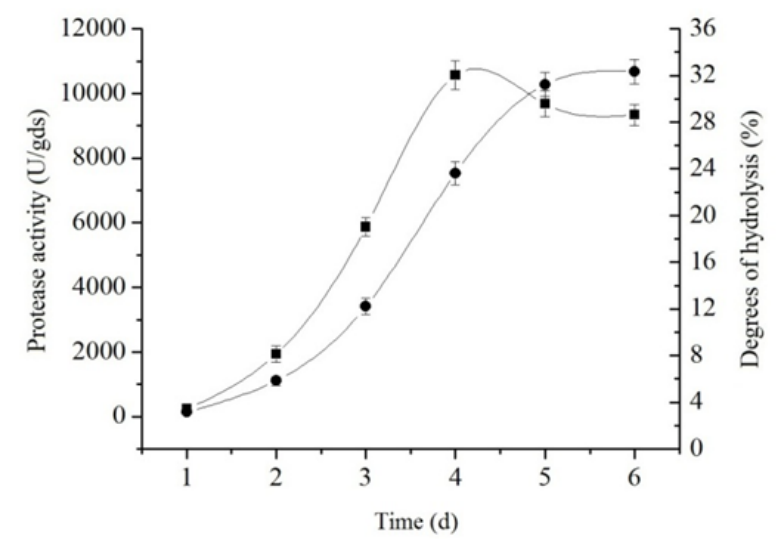

Figue 1 - Time course of changes in protease yield ( $\mathbf{\square})$ and degree of hydrolysis of proteins $(\bullet)$.

Beyond 4 days of cultivation, a decrease in the protease production was observed, which can be explained by several reasons, such as $\mathrm{pH}$ variation production of amino acids and low-molecularweight compounds. The DH increased slowly on the initial 2 days, and then increased almost linearly with increasing cultivation time from 2 days to 5 days. Thereafter, the $\mathrm{DH}$ reached a plateau at $32.32 \%$. In addition, when the Acanthogobius hasta processing by-product proteins fermented for 5 days, the $\mathrm{DH}$ increased slightly. This type of DH versus incubation time curve is very typical and very similar to that for hydrolysis of proteins with commercial proteases. Similar result has been reported for hydrolysis of sardinelle head and viscera, yellow stripe trevally tuna spleen, salmon by-products, and scallop and abalone muscle. The authors speculated that the decrease in hydrolysis rate maybe due to the formation of reaction products, the decrease in concentration of peptide bonds available for hydrolysis, enzyme inhibition and enzyme deactivation (Zhou et al. 2012). Moreover, the results indicate that by the 5 days of fermentation, the Acanthogobius hasta processing by-product proteins were hydrolyzed to peptides by proteases produced by Aspergillus oryzae during fermentation.

\section{Antioxidant activities of APs produced in solid state fermentation}

Due to the diversity of oxidation processes and antioxidant action of protein hydrolysates, the use of a single method to evaluate the antioxidant activity cannot provide a clear idea about its real antioxidant potential (He et al. 2012). Therefore, in order to elucidate the antioxidative properties of hydrolysates obtained by solid state fermentation for $4 \mathrm{~d}, 5 \mathrm{~d}$ and $6 \mathrm{~d}$, antioxidant activities, as determined by DPPH, reducing power, and $\mathrm{Fe}^{2+}$ chelating assays of hydrolysates were investigated and depicted in Figure 2.

Scavenging activity of free radical DPPH has been widely used to evaluate the antioxidant activity of compounds to act as free radical scavengers or hydrogen donors. The hydrolysates showed DPPH radical scavenging abilities in different degrees. With the increasing of the concentration of the all hydrolysates, the DPPH scavenging activity increased. Among the different hydrolysates, the APs observed at 5 days post-fermentation with DH $31.23 \%$ exhibited the highest DPPH scavenging activity, the 6 days post-fermentation APs with DH $32.32 \%$ got the second position, while the 4 days post-fermentation APs (DH 23. $63 \%$ ) shown the lowest DPPH scavenging activity. BHA was used as a reference antioxidant in this study; its scavenging value was $79.3 \%$ at concentration of $30 \mu \mathrm{g} / \mathrm{mL}$. The radicalscavenging activity of the hydrolysates observed at 5 days post-fermentation at $6 \mathrm{mg} / \mathrm{mL}$ was $78.6 \%$, which indicated that the hydrolysates were good antioxidant peptide (Fig. 1 A). Our findings are in line with previous works reported by Cheung et al. (2007) who reported that DH was necessary for hydrolysate to exhibit potent DPPH activity. On the contrary, Intarasirisawat et al. (2012) found that as the DH of hydrolysis from defatted skipjack (Katsuwonous pelamis) roe increased, a decrease in DPPH activity was observed. This might be governed by a difference in chain length, amino acid composition, and 
amino acid side chain.

In order to further determine the antioxidant activity in another system, the reducing powers and the chelating activity of APs were characterized. On the basis of concentration, the reducing power of Aps at the range of $0-6 \mathrm{mg} / \mathrm{mL}$ was lower than that of the commercial antioxidants BHA at the range of $0-60 \mu \mathrm{g} / \mathrm{mL}$, while the chelating activity of APs was similar to that of BHA at the range of $0-60 \mu \mathrm{g} / \mathrm{mL}$. The 5 days post-fermentation APs showed the highest reducing activity and strong ferrous chelating activity (Fig. 1 B, C). Several works also reported that the DH significantly affects the reducing power and chelating activity of hydrolysates. Intarasirisawat et al. (2012) reported that the chelating activity of hydrolysates of defatted skipjack (Katsuwonous pelamis) roe peptides prepared by enzymatic method increased with increasing DH up to $40 \%$, while marked decrease when DH was $50 \%$. The peptide chain length was more likely essential for the chelating activity of hydrolysates. Peptides with smaller size were not able to form the complex with metals ( $\mathrm{Xu}$ et al. 2007).
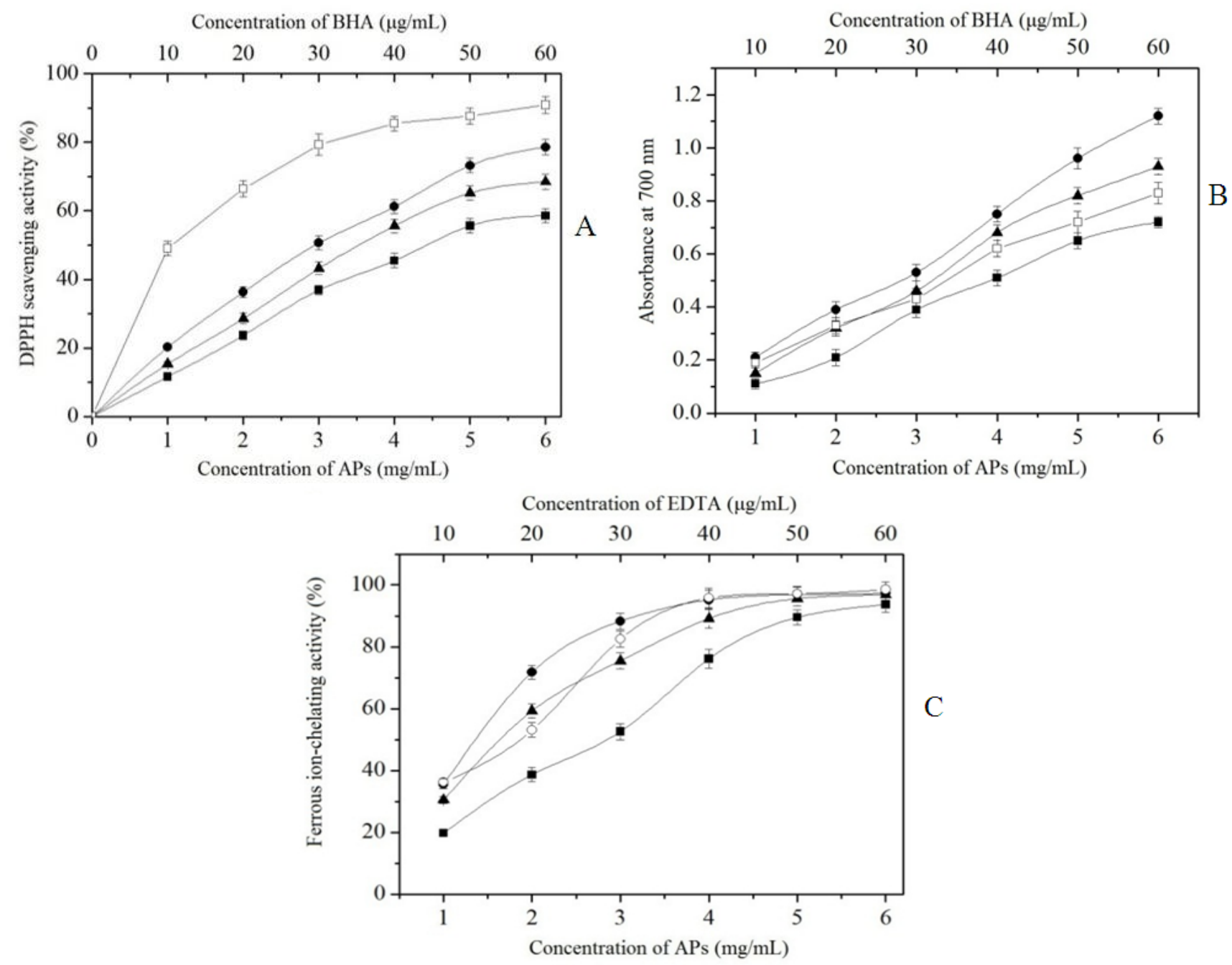

Figure 2 - A- Scavenging effect on DPPH free radical, B - reducing power and C - ferrous chelating activity of APs produced in solid state fermentation for $4 \mathrm{~d}(\boldsymbol{\bullet}), 5 \mathrm{~d}(\bullet)$, and $6 \mathrm{~d}(\boldsymbol{\Delta})$ at different concentrations, BHA ( $\square$ ) or EDTA (०) was used as positive controls.

\section{Molecular weight distribution}

The molecular weight distribution of the hydrolysates with different incubation times are shown in Table 1. With increasing incubation time, the proteins and large-sized peptides decomposed into small-sized peptide gradually. 
Before inoculation, the contents of hydrolysates with molecular weight below $3 \mathrm{kDa}$ were only $7.16 \%$, while the values increased to $61.86 \%$, $69.46 \%$ and $78.16 \%$ after incubation for 4 days, 5 days, and 6 days. This showed that the protein was successfully hydrolyzed by the protease excreted from Aspergillus oryzaeI. Molecular weight is an important parameter reflecting the hydrolysis of proteins, which further correlates with the antioxidant activities of protein hydrolysates (Zhou et al. 2012). Several studies have revealed that peptides with molecular weight below $3 \mathrm{kDa}$ show the highest antioxidant activity (Yang et al. 2011). In the present study, although the 6 days post-fermentation hydrolysates has the highest concentration of small-sized peptides, the 5 days post-fermentation hydrolysates exhibited the highest antioxidant activity. This may be due to besides the size of the peptide, the amino acids, the amino acid sequence of the peptides, and the peptide structure are also been proposed to be the important factor governing antioxidant activity.

Table 1 - Molecular weight distributions of APs prepared with solid state fermentation.

\begin{tabular}{ccccccc}
\hline \multirow{2}{*}{$\begin{array}{c}\text { Incubation } \\
\text { time (day) }\end{array}$} & $\mathbf{7 1 0 ~ K d a}$ & $\mathbf{3 - 5 ~ K d a}$ & $\mathbf{2 - 3 ~ K d a}$ & $\mathbf{1 - 2 ~ K d a}$ & $\mathbf{0 . 5}-\mathbf{1 ~ K d a}$ & $<\mathbf{0 . 5 K D a}$ \\
\cline { 2 - 7 } & $86.43 \pm 4.59$ & $6.37 \pm 0.37$ & $3.63 \pm 0.32$ & $3.18 \pm 0.22$ & $0.35 \pm 0.26$ & ND \\
PBF & $23.39 \pm 0.69$ & $14.75 \pm 0.81$ & $17.21 \pm 0.58$ & $24.35 \pm 1.26$ & $10.92 \pm 1.02$ & $9.38 \pm 0.55$ \\
5 & $19.18 \pm 0.52$ & $11.36 \pm 0.66$ & $10.66 \pm 1.12$ & $25.71 \pm 0.89$ & $16.82 \pm 0.85$ & $16.27 \pm 0.79$ \\
6 & $12.39 \pm 0.49$ & $9.45 \pm 0.33$ & $10.72 \pm 0.86$ & $27.84 \pm 1.18$ & $18.31 \pm 0.86$ & $21.29 \pm 0.93$ \\
7 &
\end{tabular}

The molecular weight distribution of protein hydrolysates was analyzed using Sephadex G25 column (Nalinanon et al. 2011); ND, not detectable. Values are given as mean \pm SD from triplicate determinations.

\section{Amino acid composition}

The amino acid composition of protein hydrolysates is reported to be one of the main factors influencing on the antioxidant properties of proteins and their hydrolysates. Therefore, the amino acid composition of the APs was determined. Table 2 presents the amino acid composition of APs with different incubation times from 1 day to 6 days. The fermentation with different incubation times did not have appreciably changes on the composition of most amino acids. The results were consistent with the previous study (Zhou et al. 2012). Aspartic acid and glutamic acid were found to be higher in APs.

Table 2 - Amino acid composition APs prepared with solid state fermentation.

\begin{tabular}{lllll}
\hline \multirow{2}{*}{ Amino acid } & \multicolumn{4}{c}{ Incubation time (day) } \\
\cline { 2 - 5 } & $\mathbf{1}$ & $\mathbf{4}$ & $\mathbf{5}$ & $\mathbf{6}$ \\
\hline Aspartic acid & $8.43 \pm 0.02$ & $8.36 \pm 0.02$ & $8.51 \pm 0.01$ & $8.44 \pm 0.01$ \\
Threonine & $18.96 \pm 0.03$ & $18.93 \pm 0.05$ & $18.25 \pm 0.03$ & $18.82 \pm 0.03$ \\
Serine & $4.69 \pm 0.02$ & $4.67 \pm 0.02$ & $4.59 \pm 0.02$ & $4.53 \pm 0.01$ \\
Glutamic acid & $17.11 \pm 0.05$ & $18.03 \pm 0.02$ & $18.27 \pm 0.01$ & $18.82 \pm 0.02$ \\
Proline & $5.05 \pm 0.02$ & $5.05 \pm 0.02$ & $5.38 \pm 0.02$ & $5.23 \pm 0.02$ \\
Glycine & $7.15 \pm 0.02$ & $7.13 \pm 0.01$ & $7.12 \pm 0.02$ & $7.05 \pm 0.01$ \\
Alanine & $7.01 \pm 0.02$ & $7.06 \pm 0.02$ & $7.32 \pm 0.02$ & $7.16 \pm 0.02$ \\
Valine & $5.22 \pm 0.02$ & $5.25 \pm 0.01$ & $5.52 \pm 0.03$ & $5.23 \pm 0.01$ \\
Methionone & $3.78 \pm 0.03$ & $3.81 \pm 0.03$ & $3.96 \pm 0.05$ & $3.81 \pm 0.05$ \\
Isoleucine & $4.41 \pm 0.01$ & $4.36 \pm 0.02$ & $4.36 \pm 0.03$ & $4.23 \pm 0.03$ \\
Leucine & $7.09 \pm 0.03$ & $7.16 \pm 0.03$ & $7.55 \pm 0.04$ & $7.35 \pm 0.03$ \\
Tyrosine & $2.49 \pm 0.02$ & $2.51 \pm 0.04$ & $2.52 \pm 0.03$ & $2.58 \pm 0.02$ \\
Phenylalanine & $3.62 \pm 0.01$ & $3.73 \pm 0.01$ & $3.85 \pm 0.02$ & $3.93 \pm 0.02$ \\
Histidine & $2.25 \pm 0.01$ & $2.38 \pm 0.01$ & $2.15 \pm 0.01$ & $2.19 \pm 0.01$ \\
Tryptophan & $0.33 \pm 0.02$ & $0.36 \pm 0.03$ & $0.36 \pm 0.03$ & $0.32 \pm 0.02$ \\
Lysine & $7.45 \pm 0.02$ & $7.39 \pm 0.03$ & $7.23 \pm 0.03$ & $7.21 \pm 0.02$ \\
Arginine & $7.81 \pm 0.05$ & $7.89 \pm 0.03$ & $7.92 \pm 0.02$ & $7.99 \pm 0.02$ \\
Cysteine & $1.29 \pm 0.02$ & $1.29 \pm 0.01$ & $1.23 \pm 0.02$ & $1.25 \pm 0.01$ \\
Total hydrophobic amino acids ${ }^{\mathrm{a}}$ & 43.63 & 43.91 & 45.42 & 44.31
\end{tabular}

a, Total hydrophobic amino acids, containing Gly, Ala, Val, Met, Ile, Leu, Phe, Pro and Trp. The results represent the mean \pm standard deviation. 
Chalamaiah et al. (2012) conclude that among all the amino acids, aspartic acid and glutamic acid were found to be higher in most of the reported fish protein hydrolysates. Some studies have investigated the contribution of individual amino acid residues or groups of amino acids in some food protein hydrolysates to their antioxidant activities and reported that hydrophobic amino acid had strong positive effects on the antioxidant properties of hydrolysates (Chen et al. 1996; Zhou et al. 2012). Total hydrophobic amino acid content in the hydrolysates observed at 5 days postfermentation was found to be higher than those in the other hydrolysates. The Similar results have been also observed from silver carp (Hypophthalmichthys molitrix) hydrolysates, which showed that the highest antioxidant and free radical-scavenging activities in SCPH-V were presumably due to the highest content of total hydrophobic amino acids (Zhong et al. 2011).

\section{Functional properties}

Solubility, emulsifying properties, and foaming properties are important functional properties for proteins and their hydrolysates. Many of the protein hydrolysates require processing to provide hydrolysates having acceptable those functional properties, because the functional properties are responsible for many functional properties that influence the consumer acceptance of food products (Klomklao et al. 2013). The 5 days postfermentation APs showed the highest antioxidant activity, so their functional properties were determined with PBF as a dummy sample.

\section{Solubility}

Solubility is one of the most important functional properties of a protein and can be increased by hydrolysis process. The solubility of PBF and APs at various $\mathrm{pHs}$ ranging from 2-12 was investigated and the result showed that both PBF and APs were all soluble over a wide $\mathrm{pH}$ range. The APs with more than $88.3 \%$ solubility has better water solubility than PBF. The results showed that the 5 days post-fermentation APs can be therefore applied widely in formulated food systems. The lowest solubility of APs was noticeable at $\mathrm{pH} 4$, which was plausibly owing to the lowest repulsion of proteins at their isoelectric points.

\section{Foaming properties}

The foam expansion ability and foam stability after standing at room temperature for $30 \mathrm{~min}$ of
APs and PBF are shown in table 3. Obviously, with higher amount of peptides in APs and PBF, higher expansion ability were attained $(p<0.05)$. At the same concentration, the APs showed higher expansion ability. Intarasirisawat et al. reported that the higher concentration of APs might result in the self-aggregation and lowered the migration of peptides to the air-water interface. For foam stability, the foam stability also increased when the concentration increased $(p<0.05)$ (Intarasirisawat et al. 2012). This is also in line with other published studies on fish protein hydrolysates (Ktari et al. 2012).

Table 3 - Foaming properties of ZPHs at different concentrations.

\begin{tabular}{clccc}
\hline $\begin{array}{c}\text { Hydrolysate } \\
\text { concentration } \\
(\mathbf{m g} / \mathbf{m L})\end{array}$ & \multicolumn{2}{c}{$\begin{array}{c}\text { Foam } \\
\text { expansions (\%) }\end{array}$} & \multicolumn{2}{c}{$\begin{array}{c}\text { Foam stability } \\
(\%)\end{array}$} \\
\cline { 2 - 5 } & \multicolumn{1}{c}{ APs } & PBF & APs & PBF \\
\hline 0.5 & $43.21 \pm$ & $26.78 \pm$ & $21.95 \pm$ & $15.21 \pm$ \\
& $0.65^{\mathrm{a}}$ & $1.27^{\mathrm{a}}$ & $0.36^{\mathrm{a}}$ & $0.38^{\mathrm{a}}$ \\
1.0 & $58.68 \pm$ & $39.33 \pm$ & $38.95 \pm$ & $22.12 \pm$ \\
& $0.39^{\mathrm{b}}$ & $0.52^{\mathrm{b}}$ & $0.51^{\mathrm{b}}$ & $0.29^{\mathrm{b}}$ \\
2 & $82.21 \pm$ & $53.67 \pm$ & $50.62 \pm$ & $36.23 \pm$ \\
& $0.81^{\mathrm{c}}$ & $2.29^{\mathrm{c}}$ & $0.33^{\mathrm{c}}$ & $1.02^{\mathrm{c}}$ \\
\hline
\end{tabular}

Values are given as mean \pm SD from triplicate determinations $(n=3)$. Different letters mean significant differences between hydrolysates: $\mathrm{p}<0.05$.

\section{Emulsifying properties}

Emulsions form the basis of a huge range of food products, where those stabilized by proteins are of great interest. The emulsion activity index and the emulsion stability index of APs and dummy sample at varying protein concentrations were investigated and shown in table 4. The emulsion activity index and emulsifying stability index were in the range of $9.31-23.97 \mathrm{~m}^{2} / \mathrm{g}$ and $4.19-28.56$ min for APs, respectively, and $6.98-15.63 \mathrm{~m}^{2} / \mathrm{g}$ and 3.01-17.01 min for PBF, respectively. The results showed that solid-state Fermentation with Aspergillus oryzae could significantly improve the emulsion activity and the emulsion stability of the protein. The emulsion activity index and emulsifying stability index of the APs and PBF decreased significantly $(P<0.05)$ with increasing concentration. This is in agreement with previous report which showed that the emulsion activity index and the emulsion stability index of protein hydrolysate from defatted skipjack (Katsuwonous pelamis) roedecreased with increasing concentration (Ktari et al. 2012). At low protein concentrations, protein adsorption at the oil-water 
interface is diffusion controlled. At high protein concentration, the activation energy barrier does not allow protein migration to take place in a diffusion dependent manner leading to a lower protein concentration at the interface, in which a thinner film stabilising the oil droplet is formed (Ktari et al. 2012; Nalinanon et al. 2012).

Table 4 - Emulsifying properties of APs at various concentrations.

\begin{tabular}{|c|c|c|c|c|}
\hline \multirow{2}{*}{$\begin{array}{c}\text { Hydrolysate } \\
\text { concentration } \\
(\mathrm{mg} / \mathrm{mL})\end{array}$} & \multicolumn{2}{|c|}{$\begin{array}{c}\text { Emulsifying activity } \\
\text { index }\left(\mathrm{m}^{2} / \mathrm{g}\right)\end{array}$} & \multicolumn{2}{|c|}{$\begin{array}{c}\text { Emulsion stability } \\
\text { index (min) }\end{array}$} \\
\hline & APs & PBF & APs & PBF \\
\hline \multirow{2}{*}{0.5} & $23.97 \pm$ & $15.63 \pm$ & $28.56 \pm$ & $17.01 \pm$ \\
\hline & $0.38^{\mathrm{a}}$ & $0.35^{\mathrm{a}}$ & $0.43^{\mathrm{a}}$ & $0.53^{\mathrm{a}}$ \\
\hline \multirow[b]{2}{*}{1.0} & $12.52 \pm$ & $11.03 \pm$ & $7.95 \pm$ & $6.65 \pm$ \\
\hline & $0.26^{\mathrm{b}}$ & $0.29^{\mathrm{b}}$ & $0.15^{\mathrm{b}}$ & $0.55^{\mathrm{b}}$ \\
\hline \multirow[b]{2}{*}{2} & $9.31 \pm$ & $6.98 \pm$ & $4.19 \pm$ & $3.01 \pm$ \\
\hline & $0.31^{\mathrm{c}}$ & $0.52^{\mathrm{c}}$ & $0.11^{\mathrm{c}}$ & $0.37^{\mathrm{c}}$ \\
\hline
\end{tabular}

Values are given as mean \pm SD from triplicate determinations $(n=3)$. Different letters mean significant differences between hydrolysates: $\mathrm{p}<0.05$.

\section{CONCLUSION}

The protein hydrolysates from Acanthogobius hasta processing by-product, exerting good functionalities and antioxidant activities, could be achieved by solid state fermentation with Aspergillus oryzae. The 5 days post-fermentation APs exhibited the highest antioxidant activity, which were related to their molecular weight and amino acid composition, and also exhibited high solubility and interfacial properties. Thus, the APs could be used in food systems as a natural antioxidant to prevent the lipid oxidation.

\section{ACKNOWLEDGEMENTS}

We would like to thank the National Natural Science Foundation of China (31271929), the National Key Technology R\&D Program of China (2012BAC07B03), the National Marine Research Special Fund for Public Welfare Projects of China (201205020); Jiangsu Province and Technology Support Program (BE2013662), Special funds from the Jiangsu Provincial Natural Science Foundation (BK20141249), Natural Science Foundation of the Jiangsu Higher Education Institutions of China (13KJB550003), Qing Lan Project, The Project Sponsored by the Scientific Research Foundation for the Returned Overseas Chinese Scholars, State Education Ministry, and A
Project Funded by the Priority Academic Program Development of Jiangsu Higher Education Institutions.and the Priority Academic Program Development of Jiangsu Higher Education Institutions.

\section{REFERENCES}

Battaglino RA, Huergo M, Pilosof AMR, Bartholomai GB. Culture requirements for the production of protease by Aspergillus oryzae in solid state fermentation. Appl Microbiol Biotechnol. 1991; 35: 292-296.

Belmessikh A, Boukhalfa H, Mechakra-Maza A, Gheribi-Aoulmi Z, Amrane A. Statistical optimization of culture medium for neutral protease production by Aspergillus oryzae. Comparative study between solid and submerged fermentations on tomato pomace. J Taiwan Inst Chem Eng. 2013; 44: 377-385.

Bhaskar N, Benila T, Radha C, Lalitha RG. Optimization of enzymatic hydrolysis of visceral waste proteins of Catla (Catla catla) for preparing protein hydrolysate using a commercial protease. Bioresource Technol. 2008; 99: 335-343.

Bradford MM. A rapid and sensitive method for the quantification of microgram quantities of protein utilizing the principle of protein-dye binding. Anal Biochem. 1976; 72: 248-254.

Castro-Cesena AB, Sanchez-Saavedra MP, MarquezRocha FJ. Characterisation and partial purification of proteolytic enzymes from sardine by-products to obtain concentrated hydrolysates. Food Chem. 2012; 135: 583-589.

Chalamaiah M, kumar BD, Hemalatha R, Jyothirmayi T. Fish protein hydrolysates: proximate composition, amino acid composition, antioxidant activities and applications: a review. Food Chem. 2012; 135: 30203038.

Chen HM, Muramoto K, Yamauchi F, Nokihara K. Antioxidant activity of designed peptides based on the antioxidative peptide isolated from digests of a soybean protein. J Agric Food Chem. 1996; 44: 26192623.

Dhillona GS, Oberoia HS, Kaurb S, Bansald S, Brarb SK. Value-addition of agricultural wastes for augmented cellulase and xylanase production through solid-state tray fermentation employing mixed-culture of fungi. Ind Crops Prod. 2011; 34: 1160-1167.

Cheung IWY, Cheung LKY, Tan NY, Li-Chan ECY. The role of molecular size in antioxidant activity of peptide fractions from pacific hake (Merluccius productus) hydrolysates. Food Chem. 2007; 134: 1297-1306. 
Cho JY, Yang X, Park KH, Park HJ, Park SY, Moon $\mathrm{JH}$, et al. Isolation and identification of antioxidative compounds and their activities from Suaeda japonica. Food Sci Biotechnol. 2013; 22: 1547-1557.

Fang Y, Liu S, Wang S, Lu M, Jiao Y, Liu X. Preparation of antioxidant protein hydrotysate derived from Acanthogobius hasta muscle by solid state fermentation. Fisheries Sci. 2013; 32: 205-209.

Fang Y, Yu B, Wang S, Xu W, Liu S, Lu M, et al. Production of polypeptides derived from Acanthogobius hasta muscle by fermentation and assessment of their antioxidant activity. Food Sci. 2010; 31: 298-301.

Halliwell B, Gutteridge JMC. Oxygen-free radicals and iron in relation to biology and medicine. Some problems and concepts. Arch Biochem Biophys. 1986; 246: 501-514.

He R, Ju X, Yuan J, Wang L, Girgih AT, Aluko RE. Antioxidant activities of rapeseed peptides produced by solid state fermentation. Food Res Int. 2012; 49: 432-438.

Intarasirisawat R, Benjakul S, Visessanguan $\mathrm{W}, \mathrm{Wu}$ J. Antioxidative and functional properties of protein hydrolysate from defatted skipjack (Katsuwonous pelamis) roe. Food Chem. 2012; 135: 3039-3048.

Je J, Lee K, Lee MH, Ahn C. Antioxidant and antihypertensive protein hydrolysates produced from tuna liver by enzymatic hydrolysis. Food Res Int. 2009; 42: 1266-1272.

Je J, Qian Z, Byun H, Kim, S. Purification and characterization of an antioxidant peptide obtained from tuna backbone protein by enzymatic hydrolysis. Process Biochem. 2007; 42: 840-846.

Khantaphant S, Benjakul S. Comparative study on the proteases from fish pyloric caeca and the use for production of gelatin hydrolysate with antioxidative activity. Comp Biochem Physiol B Biochem Mol Biol. 2008, 151: 410-419.

Klomklao S, Benjakul S, Kishimura H. Functional properties and antioxidative activity of protein hydrolysates from toothed ponyfish muscle treated with viscera extract from hybrid catfish. Int J Food Sci Tech. 2013; 48:1483-1489.

Kim Mj, Lee JH, Jang EY, Kim JY, Kim OH, Kim MS, et al. Antioxidant and pro-oxidant activities of nhexane hxtracts from vegetables and by-products of agricultural products in bulk oils at 60 and $140^{\circ} \mathrm{C}$ heating. Food Sci Biotechnol. 2013; 22: 1262-1267.
Ktari N, Jridi M, Bkhairia I, Sayari N, Salah RB, Nasri M. Functionalities and antioxidant properties of protein hydrolysates from muscle of zebra blenny (Salaria basilisca) obtained with different crude protease extracts. Food Res Int. 2012; 49: 747-756.

Kunitz M. Crystalline soybean trypsin inhibitor. J Gen Physiol. 1947; 30: 291-310.

Li X, Luo, Y, Shenb H, You J. Antioxidant activities and functional properties of grass carp (Ctenopharyngodon idellus) protein hydrolysates. J Sci Food Agric. 2012; 92: 292-298.

Martins VG, Palezi SC, Costa JAV, Prentice C. Hydrolysis of insoluble fish protein residue from white mouth croaker (Micropogonias furnieri) by fungi. Braz Arch Biol Technol. 2014; 57, 96-102.

Nalinanon S, Benjakul S, Kishimura H, Shahidi F. Functionalities and antioxidant properties of protein hydrolysates from the muscle of ornate threadfin bream treated with pepsin from skipjack tuna. Food Chem. 2011; 124: 1354-1362.

Sandhya C, Sumantha A, Szakacs G, Pandey A. Comparative evaluation of neutral protease production by Aspergillus oryzae in submerged and solid-state fermentation. Process Biochem. 2005; 40: 2689-2694.

Xu X, Katayama S, Mine Y. Antioxidant activity of tryptic digests of hen egg yolk phosvitin. J Sci Food Agric. 2007; 87: 2604-2608.

Yang B, Yang H, Li J, Li Z, Jiang Y. Amino acid composition, molecular weight distribution and antioxidant activity of protein hydrolysates of soy sauce lees. Food Chem. 2011; 124: 551-555.

Zhong S, Ma C, Lin Y, Luo Y. Antioxidant properties of peptide fractions from silver carp (Hypophthalmichthys molitrix) processing by-product protein hydrolysates evaluated by electron spin resonance spectrometry. Food Chem. 2011; 126: 1636-1642.

Zhou D, Tang Y, Zhu B, Qin L, Li D, Yang J, et al. Antioxidant activity of hydrolysates obtained from scallop (Patinopecten yessoensis) and abalone (Haliotis discus hannai Ino) muscle. Food Chem. 2012; 132: 815-822.

Zhong S, Ma C, Lin YC, Luo Y. Antioxidant properties of peptide fractions from silver carp (Hypophthalmichthys molitrix) processing by-product protein hydrolysates evaluated by electron spin resonance spectrometry. Food Chem. 2011; 126: 1636-1642. 